\title{
Novel microcosm system for investigating the effects of elevated carbon dioxide and temperature on intertidal organisms
}

\author{
Helen S. Findlay ${ }^{1, *}$, Michael A. Kendall ${ }^{1}$, John I. Spicer ${ }^{2}$, Carol Turley ${ }^{1}$, \\ Stephen Widdicombe ${ }^{1}$ \\ ${ }^{1}$ Plymouth Marine Laboratory, Prospect Place, West Hoe, Plymouth PL1 3DH, UK \\ ${ }^{2}$ Marine Biology and Ecology Research Centre, School of Biological Sciences, University of Plymouth PL4 8AA, UK
}

\begin{abstract}
In addition to the predicted rise in temperature, a recognised consequence of increased atmospheric $\mathrm{CO}_{2}$ is ocean acidification. The response of marine organisms to the stresses associated with acidification is still not understood, and a number of recent experiments have addressed this problem. The starting point for many of these studies has been the development of a system by which seawater $\mathrm{pH}$ can be altered and then maintained. The current paper presents details of a temperature- and $\mathrm{pH}$-controlled microcosm system, which enables the establishment of a tidal regime, for the experimental investigation of intertidal organisms. Two climate scenarios were simulated to evaluate the system's precision and accuracy; Year 2008 ('low' $\left[\mathrm{CO}_{2}\right]$ : $380 \mathrm{ppm}$ and $14^{\circ} \mathrm{C}$ ) conditions and Year 2100 ('high' $\left[\mathrm{CO}_{2}\right]$ ) conditions (based on the IPCC - Intergovernmental Panel on Climate Change2007 A2 scenario, 'high' [CO ${ }_{2}$ ]: $1250 \mathrm{ppm}$ and 2.0 to $5.4^{\circ} \mathrm{C}$ warming). The temperature and seawater carbonate chemistry were reliably maintained for $30 \mathrm{~d}$ during which time newly settled barnacle cyprids were allowed to metamorphose into juveniles, then grow and develop. The $\mathrm{pH}$ and $\left[\mathrm{CO}_{2}\right]$ had $95 \%$ confidence intervals of \pm 0.03 units and $\pm 17 \mathrm{ppm}$, respectively, under low $\left[\mathrm{CO}_{2}\right]$ conditions, and of \pm 0.02 units and $\pm 43 \mathrm{ppm}$, respectively, under high $\left[\mathrm{CO}_{2}\right]$ conditions. The tidal regime is fully adjustable, and on this occasion was set to a $6 \mathrm{~h}$ cycle. These microcosms have proved ideal for studying benthic organisms from a variety of near-surface environments and at different stages of their life-cycle.
\end{abstract}

KEY WORDS: Ocean acidification $\cdot \mathrm{pH} \cdot$ Carbon dioxide $\cdot$ Climate change $\cdot$ Global warming Microcosm $\cdot$ Intertidal $\cdot$ Larvae

\section{INTRODUCTION}

Increasing atmospheric $\left[\mathrm{CO}_{2}\right]$ is causing a rapid decrease in seawater $\mathrm{pH}$ (ocean acidification) as a result of the imbalance between the rate of $\mathrm{CO}_{2}$ uptake into the ocean and the ocean's ability to buffer the resulting increase in hydrogen ions (Caldeira \& Wickett 2003). Seawater $\mathrm{pH}$ has declined by an average of 0.1 units since the industrial revolution (Kleypas et al. 2006). It is estimated that $\mathrm{pH}$ will decrease from a current global average of $\sim 8.1$ to as low as $\sim 7.7$ by 2100 (IPCC 2007). Not only does this decline in $\mathrm{pH}$ have the potential to induce hypercapnia and acidosis in some marine organisms (e.g. Pörtner et al. 2004, Shirayama \& Thornton 2005, Miles et al. 2007), but, for organisms that produce calcium carbonate structures (like corals or molluscs), there may be an additional impact on the calcification rate due to declining saturation states of calcium carbonate minerals (e.g. Fabry 1990, Gattuso et al. 1998a, Orr et al. 2005).

Atmospheric and sea-surface temperatures (SSTs) are also increasing (e.g. Levitus et al. 2005, Mackenzie \& Sciedek 2007): global SST has increased by 0.76 (ranging between 0.57 and $0.95^{\circ} \mathrm{C}$ ) from between 1850 and 1899 to between 2001 and 2005 (IPCC 2007). While climate change is increasingly recognised as an 
impact to whole marine ecosystems (e.g. coral reefs: Burke \& Maidens 2004; Arctic marginal sea ice: Loeng et al. 2005) and the geographic distribution of key pelagic and benthic species (e.g. Southward et al. 1995, Beaugrand \& Reid 2003, Hays et al. 2005, IPCC 2007), the concern over the radical changes in the ocean carbonate cycle and how this impacts marine organisms is only just emerging (Pörtner et al. 2005, Raven et al. 2005, Turley et al. 2006, Guinotte et al. 2006). It is therefore not surprising that there are even fewer studies on the relationships between temperature and acidification and how they interact to affect individual animals' physiology and impact ecosystem processes (e.g. Metzger et al. 2007).

Early experiments investigating physiological responses of marine organisms to various gas mixtures were initially carried out using relatively crude techniques of saturating water with the gas (e.g. $\mathrm{CO}_{2}$ ) and then diluting with normal seawater before adding the test animal (e.g. Fox \& Johnson 1934). Experiments were aimed primarily at eliciting a physiological response and not at replicating realistic environment conditions; hence, $\left[\mathrm{CO}_{2}\right]$ was often very high, and accurate monitoring of levels was not of primary importance (e.g. Dale et al. 1970). The methods mentioned above and some that followed, involved sealing the experimental containers once the treated water had been added, restricting the size of organisms that could be used because of the build-up of wastes in the containers and changes in the gas mixtures by respiration and by diffusion. Regulated flows of gases, mixed using precision gas mixing pumps prior to bubbling through seawater, were developed to enable more accurate control of the final gas concentrations (Pörtner 1987, Cameron \& Iwama 1987). These pumps are expensive and therefore in relatively short supply, which prevented large numbers of treatments and long exposure times from being used.

As $\left[\mathrm{CO}_{2}\right]$ and $\mathrm{pH}$ became more topical with respect to environmental change, techniques were developed to regulate seawater $\mathrm{pH}$ using $\mathrm{pH}$ sensors via feedback systems coupled to a regulated source of $\mathrm{CO}_{2}$. This greatly improved the long-term reliability and still remains one of the most implemented techniques to date (Riebesell et al. 1993, Pörtner et al. 1998, Green et al. 2004, Kurihara \& Shirayama 2004, Kurihara et al. 2004, Michaelidis et al. 2005, Metzger et al. 2007, Widdicombe \& Needham 2007). These systems, however, can be expensive and still rely on $\mathrm{pH}$ measurements for control, and not on precise measurements of $\mathrm{CO}_{2}$. Adding pulses of $\mathrm{CO}_{2}$ gives a stable $\mathrm{pH}$, on average, but the pulsing of $\mathrm{CO}_{2}$ may alter the equilibrium of the carbonate system and cause variability in total dissolved inorganic carbon (DIC). Fluctuations in the carbonate system can be accounted for by additionally monitoring DIC and/or total alkalinity $\left(A_{\mathrm{T}}\right)$. Use of these systems to investigate longer term seasonal variations is more challenging and has yet to be accurately carried out.

An alternative method developed more recently for investigating realistic environmental scenarios is the 2-phase system (Delille et al. 2005). The tops of these in situ mesocosms were isolated from the surrounding atmosphere forming tents that covered $>90 \%$ of each mesocosm surface area. The atmospheric $\left[\mathrm{CO}_{2}\right]$ in each tent was then controlled by continuous addition of high- $\left[\mathrm{CO}_{2}\right]$ air mixes. The seawater carbonate system was allowed to develop naturally and equilibrate with the atmosphere. This particular set-up involved the use of premixed gases; these types of premixed gases have also been used in experiments to bubble into seawater (e.g. Pane \& Barry 2007). Premixed gases are readily available, but are expensive and rapidly used up making long-running experiments costly.

These previous methods have been designed for mimicking subtidal situations. However, the intertidal is a significant component of the shallow-water ocean margin, is important in the global carbon cycle (Gattuso et al. 1998b, Ver et al. 1999, Chen et al. 2003, 2004) and is a key habitat for many calcifying organisms. As yet, there is no published account of experimental apparatus that enables the combined effects of higher seawater temperatures and lower $\mathrm{pH}$ on intertidal habitats/organisms to be investigated.

Building on the experience of Widdicombe \& Needham (2007) and J. I. Spicer (pers. obs.); we developed a flow-through tidal microcosm system that allows the investigator to simultaneously manipulate temperature and $\mathrm{CO}_{2}$ to simulate a realistic intertidal scenario. The system was designed primarily with the aim of investigating survival, growth and development of larvae, juveniles and adults of species from the intertidal zone; it is also clearly a suitable experimental tool for tackling a wide range of questions related to the development, settlement and growth of intertidal organisms. The incorporation of a cheap, yet reliable gas mixing system builds on previous gas mixing techniques, allowing the investigator to easily control the gas mix over long periods of time (weeks, months). The small scale of the system allows it to be portable between laboratories and flexible with respect to the variety of organisms that can be studied. The stability, precision and reproducibility of this system have been assessed by investigating the response of benthic postlarva to the experimental conditions created by this system. The target conditions and variability of the system are discussed in comparison to a similar experiment conducted using the mescocosm system of Widdicombe \& Needham (2007) and data extracted from the literature. 


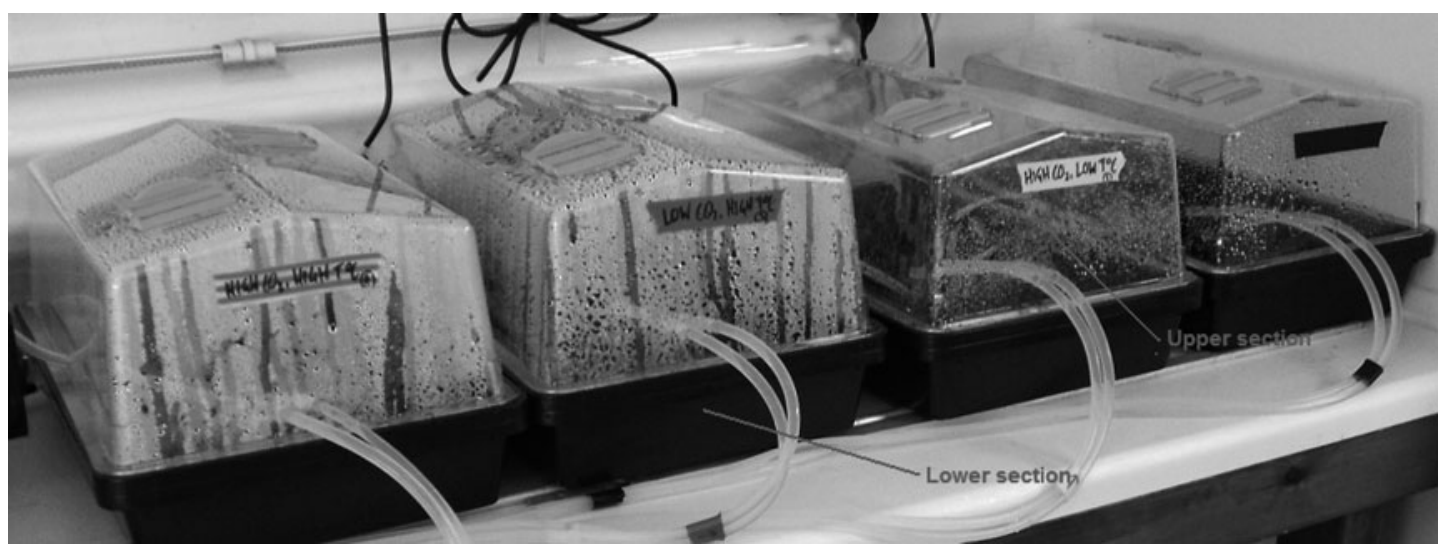

Fig. 1. Four tidal microcosms showing the upper and lower sections and water inflow pipes

\section{MATERIALS AND METHODS}

The microcosms. Microcosms were constructed by adapting variable controlled, commercially available $(B \& Q)$, electric-heated plant propagators $(30 \times 15 \times$ $20 \mathrm{~cm}$ ). Each microcosm consisted of 2 parts: a lower section containing the internal heating elements and an upper section (Fig. 1). The heating elements were connected to an enclosed controllable thermostat, which regulated the temperature, via a thermocouple, to between ambient (in this case $14^{\circ} \mathrm{C}$ ) and $40^{\circ} \mathrm{C}$ $( \pm 0.01)$; the heat was spread evenly throughout the

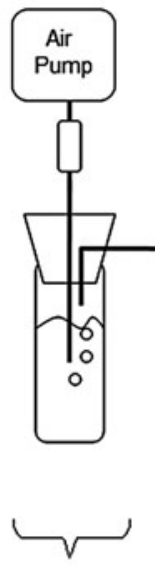

(1)

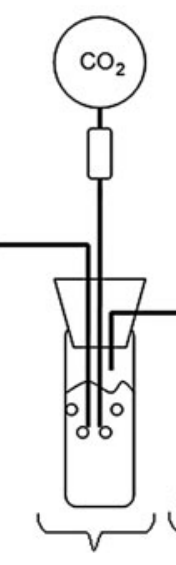

(2)

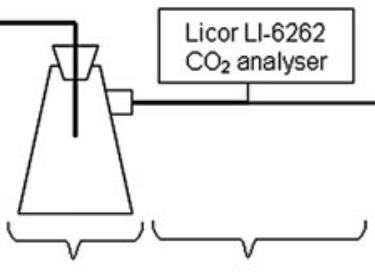

(3)
(4)
Fig. 2. Air $-\mathrm{CO}_{2}$ mixing system consisting of (1) air pumped through a flow meter into a mixing vessel containing sodalime to remove the $\mathrm{CO}_{2}$, (2) pure $\mathrm{CO}_{2}$ pumped through a flow meter into a mixing vessel along with the $\mathrm{CO}_{2}$-free air, (3) mixed high- $\left[\mathrm{CO}_{2}\right]$ air flows into another vessel to dry the air before (4) passing through a Licor air analyser and on to the microcosms. The tidal system (5) consists of several microcosms connected to the high- $\left[\mathrm{CO}_{2}\right]$ air or normal air, and to seawater controlled by 2 pumps: an inflow pump ( $6 \mathrm{~h}$ on/off cycle) and an outflow pump (on $24 \mathrm{~h}$ ) lower section. The upper section contained 2 adjustable vents, which prevented a build-up of gas that might otherwise have occurred from the constant addition of high- $\left[\mathrm{CO}_{2}\right]$ air. In each microcosm there were water input and outlet pipes and an air/high- $\left[\mathrm{CO}_{2}\right]$ air input pipe. The air input pipe had an aquarium air stone attached to maintain fine air bubbling into the bottom of the lower section.

The ambient system discussed here was set up for current southwest UK seawater temperatures, which range from about 8 to $15^{\circ} \mathrm{C}$; however, alternative temperatures can be achieved most simply by setting up the experimental system in a suitable controlled temperature/environment room. The use of chillers and heaters (e.g. an Aqua Medic Minicooler) would also be possible, depending on the size of the containers used as microcosms. 
$\mathbf{C O}_{2}$ manipulation. The concentration of $\mathrm{CO}_{2}$ flowing into the microcosms was manipulated through an air- $\mathrm{CO}_{2}$ gas mixing system (Fig. 2). In this system, air was pumped through a flow meter (1 in Fig. 2), into an airtight and pressure-resistant bottle (e.g. a 1 l Dreschel mixing bottle) containing $4 \% \mathrm{NaOH}$, which both cleaned the air and removed the $\mathrm{CO}_{2}$. Carbon dioxide (BOC, CP grade carbon dioxide $99.995 \%$ ) (2 in Fig. 2) was pumped through a second flow meter into a second airtight and pressure-resistant bottle (in this case a $1 \mathrm{l}$ Buchner mixing flask) containing distilled water. The cleaned air was also passed into this mixing flask, and the use of aquarium air stones, which created fine bubbles of both $\mathrm{CO}_{2}$ and air, allowed the 2 gases to mix. The mixed high- $\left[\mathrm{CO}_{2}\right]$ air then fed into a final airtight and pressure-resistant bottle (3 in Fig. 2; here a 1 l Buchner flask) before flowing through a Licor LI-6262 $\mathrm{CO}_{2}$ analyser (4 in Fig. 2) and then out to the microcosms. The flow rates of the air and the $\mathrm{CO}_{2}$ were adjusted to create the final high- $\left[\mathrm{CO}_{2}\right]$ air mix; for example, to create a $\left[\mathrm{CO}_{2}\right]$ of $1250 \mathrm{ppm}$, a flow of $6.25 \mathrm{ml} \mathrm{min}^{-1}$ of $\mathrm{CO}_{2}$ needs to be mixed with cleaned air flowing at $51 \mathrm{~min}^{-1}$. The composition of the mixture was monitored using the $\mathrm{CO}_{2}$ analyser. The high- $\left[\mathrm{CO}_{2}\right]$ air was bubbled continuously into the lower section of the microcosms using air stones (see above), allowing the seawater $\left[\mathrm{CO}_{2}\right]$ to reach equilibrium. The control (low $\left[\mathrm{CO}_{2}\right]$ ) microcosms were bubbled with ambient air pumped using a Hailea air pump (Model V-20). Standard aquarium connectors and valves were used to connect non-porous silicone tubing to the air stones. The bubbling rate was controlled using standard aquarium valves, producing a flow rate of about $50 \mathrm{~cm}^{3}$ $\mathrm{min}^{-1}$ into each microcosm. To produce a greater flow rate overall, an additional valve was constantly open to release the remaining air flow. The $\mathrm{pH}$ (NBS scale) and $\left[\mathrm{CO}_{2}\right]$ were measured as the microcosms were filled with water (see 'Evaluation of microcosm' below).

To investigate a wide range of $\mathrm{CO}_{2}$ concentrations, the $\mathrm{CO}_{2}$ manipulation set-up would need to be replicated for each $\mathrm{CO}_{2}$ concentration, with the exception of using 1 Licor $\mathrm{CO}_{2}$ analyser to periodically analyse all the different $\mathrm{CO}_{2}$ concentrations. An improvement (although more expensive) to this set-up would be to use digital flow meters (e.g. use of a standard solenoid valve coupled to a millivolt controller), to monitor the pressure and flow regulating the $\mathrm{CO}_{2}$ and air flow accordingly and, thus, to maintain a precise $\mathrm{CO}_{2}$-air mix.

Tidal mechanism. The mechanism used to mimic tidal conditions is presented in in Fig. 2 (5). A peristaltic pump (Pump 1; Watson-Marlow 503S $6 \mathrm{~h}$ on/off cycle, manipulated with a commercially available electrical timer) was used to pump seawater from a reservoir $($ volume $=15 \mathrm{l}$, salinity $=35.7 \mathrm{psu}$ ) into each micro- cosm. A second pump (Pump 2) continually pumped the seawater out of the microcosms back into the seawater reservoir. This produced a tidal cycle of low tide (microcosms are empty), flooding tide (Pump 1 on, Pump 2 on, microcosms take $6 \mathrm{~h}$ to fill), high tide (full microcosms) and ebbing tide (Pump 1 off, Pump 2 on, microcosms take $6 \mathrm{~h}$ to empty). Peristaltic pump tubing (Gradko International Ltd 116-0536-18) and silicone tubing (Fisher Scientific FB56471) were used to feed seawater through the system.

The outflow pump was set to produce a flow rate of $8.3 \mathrm{ml} \mathrm{min}^{-1}$ so as to remove $3 \mathrm{l}$ of water in $6 \mathrm{~h}_{i}$ however, it remained constantly 'on'; therefore, the inflow pump was set to a flow rate of $16.6 \mathrm{ml} \mathrm{min}^{-1}$ to fill the $3 \mathrm{l}$ microcosms during the $6 \mathrm{~h}$ flood, while allowing a continuous flow-through of water. Alternatively, digital timers can be used to set the exact tidal regime with the inflow pump turning on and the outflow pump turning off at low tide and vice versa at high tide.

Evaluation of the microcosm. To evaluate the ability of the system to reproduce a high-temperature, high$\left[\mathrm{CO}_{2}\right](\mathrm{HTHC})$ atmosphere and equilibrated seawater conditions, an experiment was conducted in which each microcosm was set up with a specific combination of temperature and $\left[\mathrm{CO}_{2}\right]$ levels. These combinations assessed the system's suitability for mimicking real climate scenarios. The experiments ran for $30 \mathrm{~d}$ in a controlled-temperature environment (precision $\pm 1^{\circ} \mathrm{C}$ ). Water measurements of $\left[\mathrm{CO}_{2}\right]$ (Model GS-136CO-1S micro $\mathrm{CO}_{2}$ electrode, Lazar Research Labs), $\mathrm{pH}$ (InLab413SG Mettler-Toledo pH meter and combination temperature electrode), temperature and salinity (WTW LF197 salinity probe) were obtained every second day at high tide. The carbonate system variables, total DIC, total $A_{\mathrm{T}}$, carbonate ion concentration and saturation states of calcite $\left(\Omega_{\text {cal }}\right)$ and aragonite $\left(\Omega_{\text {arag }}\right)$, were calculated from measured $\mathrm{pH}$ and $\left[\mathrm{CO}_{2}\right]$ data using the MatLab (Version 6.1.0.451) csys.m programme from Zeebe \& Wolf-Gladrow (2001) (www.awibremerhaven.de) and the solubility constants of Mehrbach et al. (1973).

Suitability for biological experiments. Several medium-term experiments have now been carried out using this system; these include 3 barnacle experiments using Semibalanus balanoides and Elminius modestus and 1 limpet experiment using Patella vulgata. The initial experiments on $S$. balanoides and E. modestus involved placing the animals into each of 4 tidal microcosms set at Year 2008 summer conditions characterised by low temperature $\left(14^{\circ} \mathrm{C}\right)$ and low- $\left[\mathrm{CO}_{2}\right]$ (380 ppm) (low-temperature, low- $\left[\mathrm{CO}_{2}\right]$ [LTLC] scenario) and at Year 2100 summer conditions, based on the IPCC $2007 \mathrm{~A} 2$ scenario of $4^{\circ} \mathrm{C}$ warming and a $\left[\mathrm{CO}_{2}\right]$ of $1250 \mathrm{ppm}$ (HTHC scenario) (Table 1). S. balanoides were collected by attaching settlement panels $(10 \times$ 
Table 1. Experimental conditions of temperature $(T)$, carbon dioxide concentration $\left(\left[\mathrm{CO}_{2}\right]\right)$ and pH. Data are $30 \mathrm{~d}$ mean values $\pm 95 \% \mathrm{CI}$

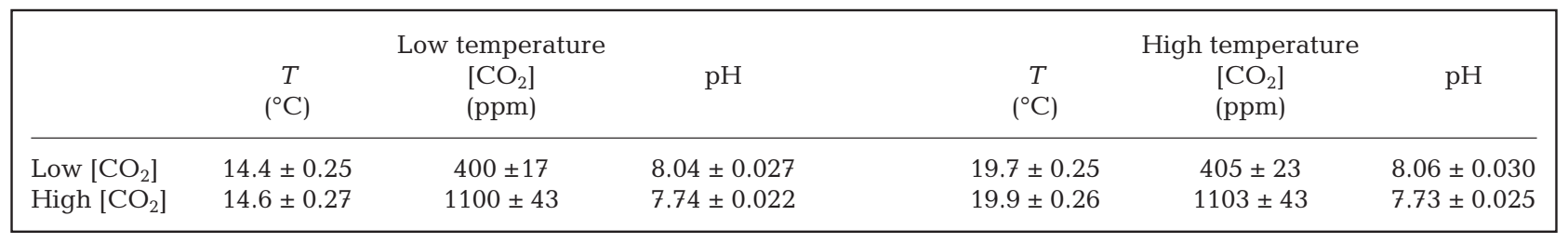

$10 \mathrm{~cm}$ tiles) to north-facing rocks mid-shore at Looe, England $\left(50^{\circ} 20^{\prime} \mathrm{N}, 004^{\circ} 27^{\prime} \mathrm{W}\right)$, for $1 \mathrm{wk}$ (beginning 30 April 2007) during barnacle settlement. On collection the panels contained a mixed age population of barnacles, ranging from newly settled cyprids to $1 \mathrm{wk}$ old metamorphosed individuals. Three settlement panels were placed in each microcosm. Photographs of each panel were taken at low tide on Days 1 and 30 and every second day in between. A stand was set up so that the camera (FujiFilm A510 FinePix digital camera) and plate were aligned consistently. The photographic images were analysed using image analysis software (Image-Pro Plus v.4.5, Media Cybernetics) to estimate both abundance (number of animals per plate) and survival (measured as numbers surviving from one day to the next). The experiment was repeated for settled E. modestus.

The limpet experiment was carried out by collecting adult limpets on small rock chips $(6 \mathrm{~cm}<$ length $<$ $30 \mathrm{~cm}$ ) from mid-shore at Looe, England, on 13 November 2007 and by placing 10 ind. in each microcosm. This experiment was run for $36 \mathrm{~d}$ in 4 microcosms - 2 replicate control microcosms $\left(T=12^{\circ} \mathrm{C}\right.$, $\left.\left[\mathrm{CO}_{2}\right]=360 \mathrm{ppm}\right)$ and 2 replicate high- $\left[\mathrm{CO}_{2}\right]$ microcosms $\left(T=12^{\circ} \mathrm{C},\left[\mathrm{CO}_{2}\right]=1250 \mathrm{ppm}\right)$. Shell measurements were made (shell length, height and width across the apex), and records of numbers surviving were maintained. Light was provided by 4 lights (Polylux XL 58W, 5200 Lm) with an 8/16 h on/off cycle.

The third barnacle experiment (Semibalanus balanoides) involved collecting adults on small rock chips from the mid-shore at Looe, England, on 23 November 2007 and placing in excess of 400 ind. in each microcosm. The experiment was run for $91 \mathrm{~d}$ in 4 microcosms -2 replicate control microcosms $\left(T=12^{\circ} \mathrm{C}\right.$, $\left.\left[\mathrm{CO}_{2}\right]=370 \mathrm{ppm}\right)$ and 2 replicate high- $\left[\mathrm{CO}_{2}\right]$ microcosms $\left(T=12^{\circ} \mathrm{C},\left[\mathrm{CO}_{2}\right]=1250 \mathrm{ppm}\right)$. Survival of barnacles, as an average for each microcosm, was calculated from photographic images analysed using image analysis software, as above. The lights (Polylux XL 58 W, $5200 \mathrm{Lm}$ ) were set to within $15 \mathrm{~min}$ of the sunrise/sunset times of London, UK, on a weekly basis; this ranged from roughly an $8 / 16 \mathrm{~h}$ on/off cycle in December, to a $9 / 15 \mathrm{~h}$ on/off cycle in January, and a 10/14 h on/off cycle in February.

\section{RESULTS}

\section{Evaluation of the microcosm}

The tidal cycle

The tidal cycle was maintained for the duration of each experiment (ca. 30 or $90 \mathrm{~d}$ ). $\left[\mathrm{CO}_{2}\right]$ varied the most over each tidal cycle (Fig. 3, triangles), but not significantly enough to affect pH and DIC (Fig. 3, circles and crosses).

\section{Measured values of $\mathrm{pH}, \mathrm{CO}_{2}$ and DIC}

In the first 2 barnacle experiments, only $\mathrm{pH}$ and $\left[\mathrm{CO}_{2}\right]$ were measured. They showed that conditions could be kept relatively stable over $30 \mathrm{~d}$ periods with only small fluctuations. The atmospheric $\left[\mathrm{CO}_{2}\right]$ was maintained, on average, at 400 and 1100 ppm, respectively, in the low- and high- $\left[\mathrm{CO}_{2}\right]$ scenarios (Table 2). The control was higher than the required $380 \mathrm{ppm}$ as result of a slight build-up of ambient $\left[\mathrm{CO}_{2}\right]$ within the laboratory. There was greater variation in the high$\left[\mathrm{CO}_{2}\right]$ scenarios: $95 \%$ CIs were \pm 9 and $\pm 12 \mathrm{ppm}$ in the low- $\left[\mathrm{CO}_{2}\right]$ scenarios and \pm 18 and \pm 14 ppm in the high$\left[\mathrm{CO}_{2}\right]$ scenarios. The seawater $\mathrm{pH}$ was thus maintained on average at $8.05 \pm 0.028$ and $8.06 \pm 0.030$, in the low$\left[\mathrm{CO}_{2}\right]$ scenarios and $7.72 \pm 0.021$ and $7.73 \pm 0.016$, in the high- $\left[\mathrm{CO}_{2}\right]$ scenarios. The pressure of the air and the $\left[\mathrm{CO}_{2}\right]$ both needed to be checked and modified throughout the experimental period to prevent any alterations in the mixing ratios. There was a slight decline in the mixing system air pressure over the experimental time period, which caused a change in the $\mathrm{pH}$ (increase by 0.03 units over $30 \mathrm{~d}$ ) and $\left[\mathrm{CO}_{2}\right]$ (decrease by $\sim 10$ ppm over $30 \mathrm{~d}$ ) in the low- $\left[\mathrm{CO}_{2}\right]$ scenarios, and opposite effects in the high- $\left[\mathrm{CO}_{2}\right]$ scenarios ( $\mathrm{pH}$ decreased by 0.04 over $30 \mathrm{~d} ;\left[\mathrm{CO}_{2}\right]$ increased by $\sim 60$ ppm over $30 \mathrm{~d}$ ).

In the subsequent experiments, the DIC was measured in addition to $\left[\mathrm{CO}_{2}\right]$ and $\mathrm{pH}$. This gave a much more stable value for DIC (Table 2), and, in turn, the calculated values of the carbonate system (see 'Results: calculated values of carbonate system variables' be- 


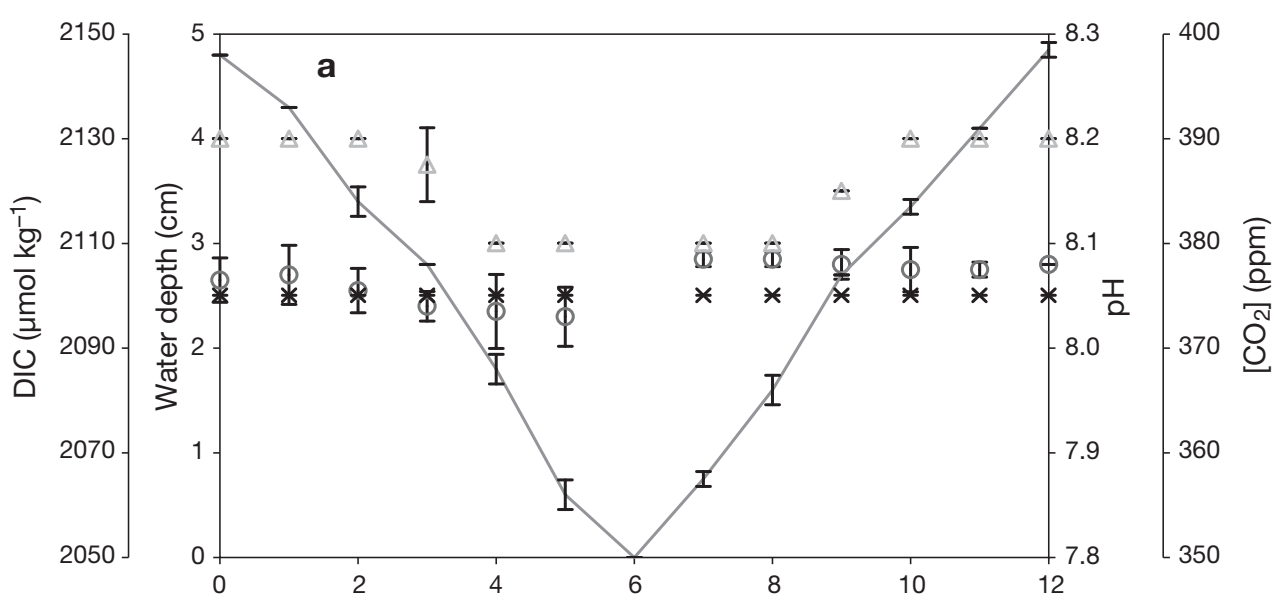

Fig. 3. Evolution of $\mathrm{pH}(\mathrm{O})$, dissolved inorganic carbon $\left(\mathrm{DIC}_{;} *\right)$ and $\left[\mathrm{CO}_{2}\right](\triangle)$ over 4 tidal cycles (data are mean $\pm 95 \%$ CI). Solid line: depth (cm) of water throughout the tidal period. (a) Low- $\left[\mathrm{CO}_{2}\right]$ treatment and (b) high- $\left[\mathrm{CO}_{2}\right]$ treatment

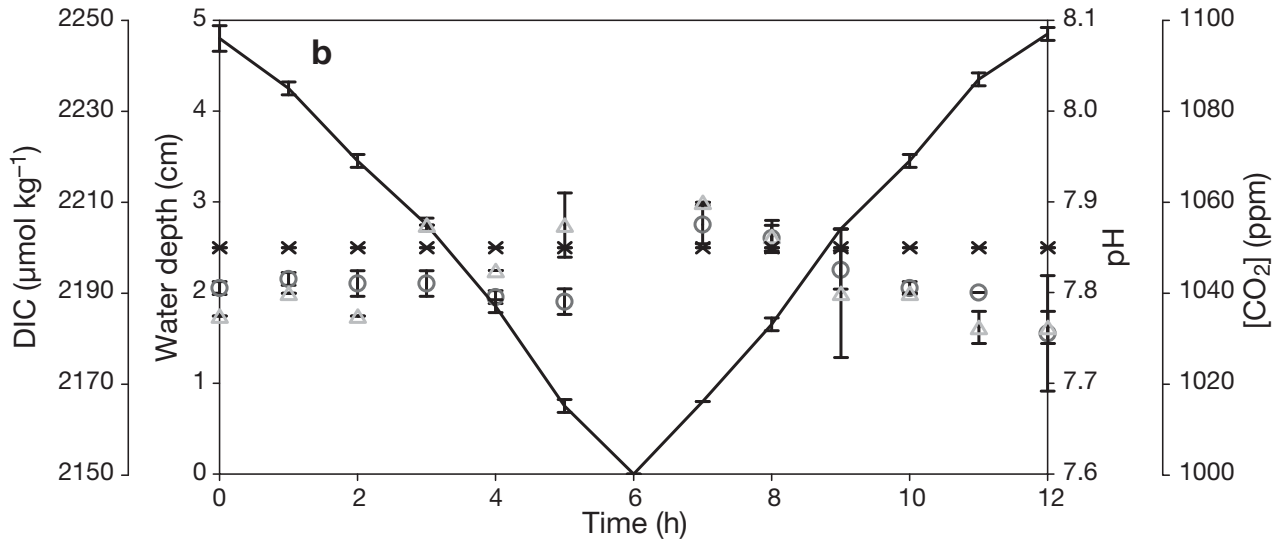

Table 2. System data (mean $\pm 95 \%$ CI) for the 4 experiments - Sb(1): 30 d Semibalanus balanoides; Em(2): 30 d Elminius modestus; $\mathrm{Pv}(3)$ : 30 d Patella vulgata; $\mathrm{Sb}(4)$ : 90 d $S$. balanoides for each treatment. For $\mathrm{Sb}(1)$ and Em(2), salinity, temperature, $\mathrm{pH}$ and $\left[\mathrm{CO}_{2}\right]$ data were measured, all other data (DIC: dissolved inorganic carbon; $A_{\mathrm{T}}$ : total alkalinity; $\Omega_{\text {calcite: calcite saturation state; }}$ $\Omega_{\text {aragonite: }}$ aragonite saturation state) were calculated from $\mathrm{pH}$ and $\left[\mathrm{CO}_{2}\right]$ using MatLab csys.m from Zeebe \& Wolf-Gladrow (2001) (www.awi-bremerhaven.de) and using the solubility constant of Mehrbach et al. (1973). For Pv(3) and Sb(4), salinity, temperature, $\mathrm{pH},\left[\mathrm{CO}_{2}\right]$ and DIC were measured; all other values were calculated from $\mathrm{pH}$ and DIC

\begin{tabular}{|c|c|c|c|c|c|c|c|c|}
\hline Treatment & $\begin{array}{l}\text { Salinity } \\
\text { (psu) }\end{array}$ & $\begin{array}{l}\text { Temp. } \\
\left({ }^{\circ} \mathrm{C}\right)\end{array}$ & $\mathrm{pH}$ & $\begin{array}{c}\text { DIC } \\
\left.(\mu \mathrm{mol} \mathrm{kg})^{-1}\right)\end{array}$ & $\begin{array}{c}A_{\mathrm{T}} \\
(\mu \mathrm{Eq} \mathrm{kg})\end{array}$ & $\begin{array}{c}{\left[\mathrm{CO}_{3}{ }^{2-}\right]} \\
\left(\mu \mathrm{mol} \mathrm{kg}{ }^{-1}\right)\end{array}$ & $\Omega_{\text {calcite }}$ & $\Omega_{\text {aragonite }}$ \\
\hline \multicolumn{9}{|l|}{ Low $\left[\mathrm{CO}_{2}\right]$} \\
\hline $\mathrm{Sb}(1)$ & $35.7 \pm 0.30$ & $14.4 \pm 0.25$ & $8.05 \pm 0.028$ & $2185 \pm 110$ & $2417 \pm 133$ & $169 \pm 18.9$ & $3.84 \pm 0.46$ & $2.42 \pm 0.23$ \\
\hline $\operatorname{Em}(2)$ & $34.5 \pm 0.33$ & $14.7 \pm 0.23$ & $7.96 \pm 0.022$ & $2003 \pm 58$ & $2192 \pm 69$ & $137 \pm 9.0$ & $3.22 \pm 0.22$ & $2.06 \pm 0.14$ \\
\hline $\operatorname{Pv}(3)$ & $36.4 \pm 0.97$ & $11.7 \pm 0.36$ & $7.93 \pm 0.030$ & $1995 \pm 106$ & $2144 \pm 114$ & $110 \pm 9.0$ & $2.44 \pm 0.21$ & $1.56 \pm 0.13$ \\
\hline $\mathrm{Sb}(4)$ & $35.5 \pm 1.43$ & $11.8 \pm 0.42$ & $8.07 \pm 0.045$ & $1968 \pm 138$ & $2163 \pm 135$ & $146 \pm 21.0$ & $3.27 \pm 0.37$ & $2.09 \pm 0.23$ \\
\hline \multicolumn{9}{|l|}{$\mathrm{High}\left[\mathrm{CO}_{2}\right]$} \\
\hline $\mathrm{Sb}(1)$ & $35.6 \pm 0.32$ & $14.8 \pm 0.27$ & $7.72 \pm 0.021$ & $2517 \pm 113$ & $2613 \pm 124$ & $95 \pm 9.1$ & $2.15 \pm 0.20$ & $1.36 \pm 0.13$ \\
\hline $\operatorname{Em}(2)$ & $34.5 \pm 0.30$ & $14.9 \pm 0.20$ & $7.73 \pm 0.051$ & $2652 \pm 301$ & $2753 \pm 329$ & $101.7 \pm 23.7$ & $2.4 \pm 0.69$ & $1.54 \pm 0.35$ \\
\hline $\operatorname{Pv}(3)$ & $36.4 \pm 0.96$ & $11.7 \pm 0.35$ & $7.63 \pm 0.040$ & $2230 \pm 105$ & $2277 \pm 106$ & $63.1 \pm 8.2$ & $1.39 \pm 0.17$ & $0.88 \pm 0.11$ \\
\hline $\mathrm{Sb}(4)$ & $35.6 \pm 1.44$ & $11.9 \pm 0.44$ & $7.689 \pm 0.055$ & $2131 \pm 160$ & $2193 \pm 149$ & $71 \pm 14.0$ & $1.58 \pm 0.25$ & $1.01 \pm 0.157$ \\
\hline
\end{tabular}

low). The $\left[\mathrm{CO}_{2}\right]$ was prevented from building up in the laboratory and was thus maintained reliably at the desired levels. In the shorter ( $30 \mathrm{~d})$ limpet experiment the mean $( \pm 95 \% \mathrm{CIs})\left[\mathrm{CO}_{2}\right]$ was $362 \pm 4.4$ and $1258 \pm$ $120 \mathrm{ppm}$ and mean $\mathrm{pH}$ levels were $7.94 \pm 0.042$ and
$7.63 \pm 0.067$, in the low and high $\left[\mathrm{CO}_{2}\right]$ scenarios, respectively. In the longer Semibalanus balanoides experiment, $\left[\mathrm{CO}_{2}\right]$ was $377 \pm 8.5$ and $1270 \pm 92 \mathrm{ppm}$, while the $\mathrm{pH}$ was $8.07 \pm 0.068$ and $7.7 \pm 0.075$, in the low and high $\left[\mathrm{CO}_{2}\right]$ scenarios, respectively. 
Temperature and salinity

In the first 2 barnacle experiments the controlledtemperature room maintained the ambient air temperature at an average of $14^{\circ} \mathrm{C}$. The seawater in the lowtemperature scenario incubators reflected the ambient air temperature in the upper sections, and these sections were maintained at $14.4 \pm 0.25$ and $14.7 \pm$ $0.28^{\circ} \mathrm{C}$ (mean $\pm 95 \% \mathrm{CI}$ ). The seawater in the hightemperature treatments was maintained by $19.8 \pm$ 0.25 and $19.7 \pm 0.27^{\circ} \mathrm{C}$, reflecting a $5^{\circ} \mathrm{C}$ increase in ambient temperature through heating of the base of each microcosm. The seawater used in the experiment had an average salinity of $35.7 \pm 0.33$ psu (Table 2).

In the winter experiments, the limpets were maintained at $11.7 \pm 0.36^{\circ} \mathrm{C}$ and $36.4 \pm 0.96 \mathrm{psu}$ ). Over the longer term Semibalanus balanoides experiment, the temperature was slowly increased from $11.1 \pm 0.1$ to $13.1 \pm 0.1^{\circ} \mathrm{C}$ ) over the $90 \mathrm{~d}$ period to reflect and increase in seawater temperature during spring. Salinity was maintained at $35.5 \pm 1.43 \mathrm{psu}$ ) over the whole period.

\section{Calculated values of carbonate system variables}

Calculated $A_{\mathrm{T}}$ and total DIC showed greater fluctuations over the initial barnacle experiments and displayed greater variation between treatments than measured $\mathrm{pH}$ and $\left[\mathrm{CO}_{2}\right]$ values (Fig. $4 \mathrm{a}$; means: $A_{\mathrm{T}}=$ $2435 \pm 98 \mu \mathrm{Eq} \mathrm{kg}{ }^{-1}$ and DIC $=2554 \pm 78 \mu \mathrm{mol} \mathrm{kg}{ }^{-1}$ in the low- $\left[\mathrm{CO}_{2}\right]$ scenarios and $A_{\mathrm{T}}=2554 \pm 76 \mu \mathrm{Eq} \mathrm{kg}{ }^{-1}$ and DIC $=2445 \pm 70 \mu \mathrm{mol} \mathrm{kg}{ }^{-1}$ in the high- $\left[\mathrm{CO}_{2}\right]$ scenarios). $\left[\mathrm{CO}_{3}{ }^{2-}\right]$ was greatest in the HTLC treatment

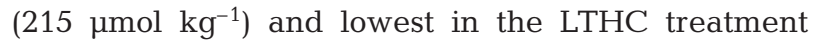
$\left(95 \mu \mathrm{mol} \mathrm{kg}{ }^{-1}\right)$, confirming that both temperature and $\left[\mathrm{CO}_{2}\right]$ have an affect on the concentration of carbonate ion in the water. The decrease in $\left[\mathrm{CO}_{3}{ }^{2-}\right]$ from the year 2008 (LTLC) to the A2 2100 scenario (HTHC) is not as large as might be expected if the concentration had been calculated using only an increased $\left[\mathrm{CO}_{2}\right]$ level and not an increased temperature level. The calcite saturation state $\left(\Omega_{\text {cal }}\right)$ does not become undersaturated in any treatment, but still falls to a level that may be marginal for dissolution of calcium carbonate; and saturation state was $>30 \%$ lower in the HTHC scenario compared to the control. The aragonite saturation state $\left(\Omega_{\text {arag }}\right)$ is again not undersaturated in any of the treatments, although it is again $30 \%$ lower in the HTHC scenario compared to the control (Fig. 4c).

In the limpet and long-term Semibalanus balanoides experiment, the measured value of DIC produced more stable values of the carbonate system
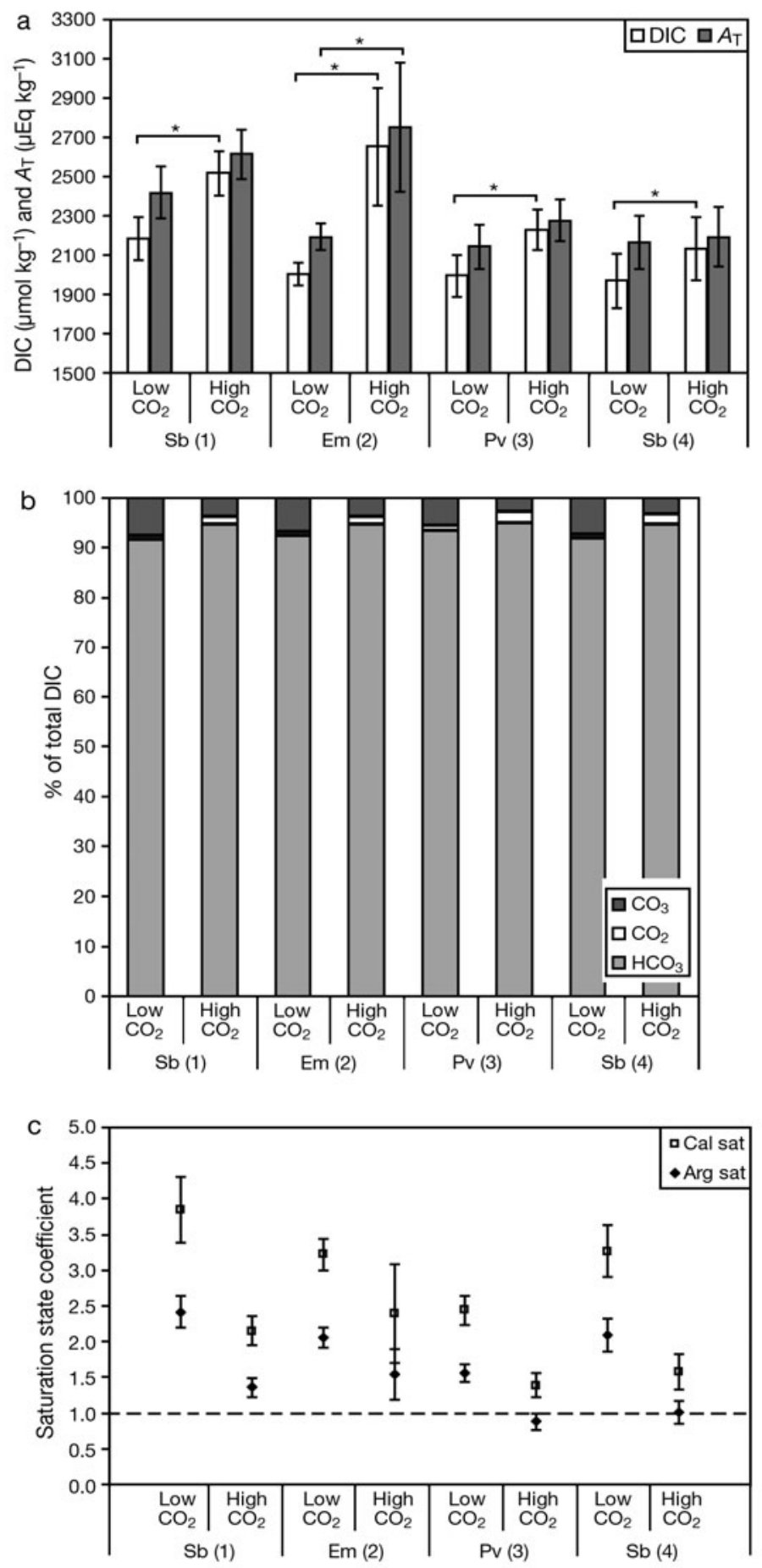

Fig. 4. (a) Mean alkalinity $\left(A_{\mathrm{T}}\right)$ and total dissolved inorganic carbon (DIC) concentrations for the low- and high- $\left[\mathrm{CO}_{2}\right]$ treatments for each experiment-Sb(1): $30 \mathrm{~d}$ Semibalanus balanoides; $\mathrm{Em}(2)$ : 30 d Elminius modestus; $\mathrm{Pv}(3)$ : 30 d Patella vulgata; $\mathrm{Sb}(4): 90 \mathrm{~d}$ S. balanoides. Error bars: $95 \%$ CIs, ${ }^{*} \mathrm{p}<0.05$. (b) Composition of DIC in each of the treatments in all experiments, given as $\mathrm{CO}_{3}{ }^{2-}$, $\left[\mathrm{CO}_{2}\right]$ and $\mathrm{HCO}_{3}{ }^{-}$percentage of total dissolved inorganic carbon. (c) Mean calcite (cal) and aragonite (arg) saturation (sat) states for each of the treatments in all experiments. Error bars: $95 \% \mathrm{CI}$, dashed line: saturation state of 1 -below this line calcite and aragonite will be undersaturated 
than just using $\mathrm{pH}$ and $\mathrm{CO}_{2}$. The low- $\left[\mathrm{CO}_{2}\right]$ mean $( \pm 95 \% \mathrm{CI})$ for DIC were $1995 \pm 106$ (limpets) and $1968 \pm 138 \mu \mathrm{mol} \mathrm{kg}{ }^{-1}$ (S. balanoides), respectively, and for alkalinity were $2144 \pm 114$ (limpets) and $2163 \pm 135 \mu \mathrm{mol} \mathrm{kg} \mathrm{kg}^{-1}$ (S. balanoides), respectively (Fig. 4a). High- $\left[\mathrm{CO}_{2}\right]$ means $( \pm 95 \% \mathrm{CI})$ for DIC and alkalinity were $2230 \pm 105$ (limpets) and $2131 \pm$ $160 \mu \mathrm{mol} \mathrm{kg}{ }^{-1}$ (S. balanoides) and $2277 \pm 106$ (limpets) and $2193 \pm 149 \mu \mathrm{mol} \mathrm{kg} \mathrm{kg}^{-1}$ (S. balanoides), respectively (Fig. 4a). Again, calcite and aragonite saturation states were reduced in the high- $\left[\mathrm{CO}_{2}\right]$ experiments, although only the limpet experiment became undersaturated with respect to aragonite (Fig. 4c; $\Omega_{\text {arg }}=0.88$ ).

\section{Biological application of the microcosm system}

By chance in the initial Semibalanus balanoides experiment, the high-temperature treatments had a greater number of longer settled individuals at the start of the experiment compared to the lowtemperature treatments. In addition to estimating the growth of all the individuals, a sub-sample of 10 similar-sized individuals on each panel was also investigated. The probability of survival was calculated as the percentage of the total number of individuals in each treatment that survived the $30 \mathrm{~d}$ experiment, multiplied by the percentage of individuals that survived in the sub-sample, to account for relative sizes. It was clear that when simulating 2008 conditions (LTLC), the system was able to maintain almost complete survivorship of barnacles $(97 \%)$. In the other treatment combinations, survivorship decreased with each treatment when the size variability was accounted for: LTHC $89 \%$, HTLC $73 \%$ and HTHC $59 \%$. In general, individuals that were small at the start of the experiment were less likely to survive, particularly in the higher temperature treatments. The increased $\left[\mathrm{CO}_{2}\right]$ treatments showed more mortality than the LTLC treatment, but the difference was not significant. When temperature and $\left[\mathrm{CO}_{2}\right]$ were both increased there was a significant reduction in cyprid and juvenile survival.

The second barnacle Elminius modestus study had a more even distribution of new and longer settled individuals. Survival was highest in the LTLC conditions (80\%) and was reduced slightly to 76,70 and $69 \%$, respectively, in the LTHC, HTLC and HTHC treatments. There was $100 \%$ survival in all limpet treatments, except in Microcosm 3 (low- $\left[\mathrm{CO}_{2}\right]$ control), where 1 individual died. In the third barnacle experiment (90 d, Semibalanus balanoides), 69\% survived on average in the controls compared to an average of $48 \%$ surviving in the low-pH treatments.

\section{DISCUSSION}

\section{Evaluation of the system}

The system described in the present paper reliably simulates the environmental conditions associated with raised atmospheric $\left[\mathrm{CO}_{2}\right]$ and temperature under a variety of climate change scenarios. We have also demonstrated the ability of this system to incorporate a tidal mechanism enabling experiments to be conducted on intertidal organisms. The success of this system is primarily a result of it being a 2 phase system in which atmospheric $\left[\mathrm{CO}_{2}\right]$ was controlled and seawater $\left[\mathrm{CO}_{2}\right]$ was able to equilibrate with the atmosphere. This provided a good simulation of the natural mechanism of oceanic uptake of $\mathrm{CO}_{2}$, but on a much smaller scale and faster timescale. Importantly, the system was able to lower and maintain seawater $\mathrm{pH}$ without significantly altering the alkalinity of the water.

Temperature was controlled to replicate the heating of rock surfaces during periods of emersion and cooling with the flood tide, thus allowing some thermal relief over the tidal cycle. Previous acidification systems have not included a heating system, although such systems have been used in global climate warming experiments (McKee et al. 2000, Baulch et al. 2003). Liboriussen et al. (2005) controlled and altered temperature in a shallow lake mesocosm system continuously for 16 mo. Their flow-through heating system was able to maintain, and vary, the temperature according to seasonal settings with little deviation from the target temperature (the deviation ranged between 0.11 and $0.26^{\circ} \mathrm{C}$ ). The seawater temperature in the system described here had larger deviations from the target temperatures of 14 and $19^{\circ} \mathrm{C}$ by $0.80( \pm 0.17)$ and $0.84^{\circ} \mathrm{C}( \pm 0.61)$, respectively, compared to Liboriussen et al. (2005). However, as with Liboriussen et al. (2005), the temperature control allows the system to be manipulated on a seasonal basis and is monitored periodically to prevent over or under heating.

The tidal section was created as a flow-through system with a relatively short water residence time $(3 \mathrm{~h})$. The tidal system enabled a $6 \mathrm{~h}$ semidiurnal tidal cycle to be used, although such a cycle deviates from both the natural general sinusoidal pattern of tidal ebb and flood and from the 6 h 12 min semidiurnal rhythm often seen in nature. The feeding rhythm of many intertidal animals is synchronised with this longer tidal cycle, and so over a long period of time animal feeding patterns may become out of synchrony with the system if they are maintained in a constant $6 \mathrm{~h}$ tidal system. The advantage of the tidal flow-through system was to prevent evaporation and salinisation in the microcosms, particularly at higher temperatures. In addition, with the incorporation of the appropriate controllers, such 
as a digitally programmable, commercially available electronic timer, a 6 h 12 min cycle, or indeed any rhythm, could be achieved.

In these experiments we did not investigate whether there was a significant build-up of nutrients or toxins in the system. We have not done so to date because of the small size of the organisms used (barnacles and recently settled limpets) compared to the high turnover rate of the water (average $0.5 \mathrm{l} \mathrm{h}^{-1}$ ). Although the seawater is recirculated through the system, this is done for about $1 \mathrm{wk}$, and then it is replaced with fresh seawater. This change was primarily done in order to prevent salinity from increasing, although it will also prevent a major build-up of toxins. The reservoir tanks hold nearly twice the amount of seawater necessary to fill the microcosms and are continually mixed by bubbling with air. If larger organisms were being used, the microcosm size would need to be increased to accommodate them. The husbandry of many common species is routine in marine laboratories, and, hence, it is relatively easy to find out the necessary turnover rates needed to prevent the organism from being affected by ammonia production, for example. If sediments are to be incorporated into the experimental set-up, we would suggest that the investigator needs to carefully consider the flow rate and the volume of the container compared to the volume of sediment, as well as taking into account the sediment depth and nutrient flux from the sediment. To prevent toxin build-up or changes in nutrients in larger systems, we would suggest either using a flow-through system in which fresh seawater is used in every tidal cycle, or incorporating filters into the recirculating system.

One major improvement to the initial barnacle experiments described here, or indeed any acidification system, would be to monitor the carbonate system better so that more appropriate parameters of the carbonate system are measured. $\mathrm{pH}$ and $\left[\mathrm{CO}_{2}\right]$ are not conservative with respect to changes in state (i.e. temperature and salinity) and thus may not be providing such an accurate account of the carbonate system as could be given by combining these measurements with either alkalinity or total inorganic carbon measurements. The latter 2 experiments described here additionally measured DIC and gave more stable carbonate system values (Table 2). A comparison of the carbonate system results from the 2 initial barnacle studies described here, together with data from the literature and a similar study, but using the experimental set-up of Widdicombe \& Needham (2007) can elucidate the stability and precision of this set-up. Table 3 demonstrates the relative $\mathrm{pH}$ values measured at each target $\left[\mathrm{CO}_{2}\right]$ in several experiments found in the literature. The $\mathrm{pH}$ SDs range from as little as 0.00 to 0.11 units. In the present study, the low- and high- $\left[\mathrm{CO}_{2}\right]$ treatments had a $\mathrm{pH}$ standard deviation of 0.06 and 0.04 units, respectively, which are within ranges of other experiments.

The additional experiments were conducted to repeat the one described here, using Elminius modestus, Patella vulgata and finally Semibalanus balanoides, but over a longer time period. The conditions remained stable over all experiments, and the precision of the first experiment was easily repeated in the others (Fig. 4). The gradual decrease in air pressure seen in the first experiment described above did not occur in the latter experiments, as we were aware of the problem and as such constantly monitored the gas pressures via the flow rates and altered the flow rates as necessary. The confidence intervals shown in Fig. 5 demonstrate that there is much better control (more accuracy) when maintaining the systems at set $\mathrm{pH}$ and $\left[\mathrm{CO}_{2}\right]$ levels using this microcosm system than a large $\mathrm{pH}$ feedback system, especially when DIC is additionally measured. It is clear that without measuring DIC or alkalinity, the calculated values are greater than

Table 3. $\mathrm{pH}$ values $( \pm \mathrm{SD})$ measured for a nominal $\left[\mathrm{CO}_{2}\right]$. Values are obtained from the literature to compare with the initial Semibalanus balanoides experiment in the present study. K04: Kurihara et al. (2004) [H.p.: Hemicentrotus pulcherrimus; E.m.: Echinometra mathaei (b: before; a: after experiment)]; S05: Shiryama et al. (2005) (1, 2 and 3: 3 replicate tanks; SDs not given in literature); Miles07: Miles et al. (2007); Mich07: Michaelidis et al. (2007)

\begin{tabular}{|c|c|c|c|c|c|c|c|c|c|}
\hline $\begin{array}{l}{\left[\mathrm{CO}_{2}\right]} \\
(\mu \mathrm{atm})\end{array}$ & $\begin{array}{c}\text { Present } \\
\text { study }\end{array}$ & $\begin{array}{c}\mathrm{K} 04 \\
(\text { H.p. }) \mathrm{b}\end{array}$ & $\begin{array}{c}\text { K04 } \\
\text { (H.p.)a }\end{array}$ & $\begin{array}{c}\mathrm{K} 04 \\
(\text { E.m. }) \mathrm{b}\end{array}$ & S05 1 & S05 2 & S05 3 & Miles07 & Mich07 \\
\hline $\begin{array}{l}\text { Control } \\
560\end{array}$ & $8.05 \pm 0.06$ & $7.99 \pm 0.10$ & $7.97 \pm 0.16$ & $8.11 \pm 0.00$ & $\begin{array}{l}7.945 \\
7.899\end{array}$ & $\begin{array}{l}7.937 \\
7.902\end{array}$ & $\begin{array}{l}7.936 \\
7897\end{array}$ & $7.96 \pm 0.07$ & $8.05 \pm 0.02$ \\
\hline $\begin{array}{l}560 \\
860\end{array}$ & & $7.74 \pm 0.02$ & $7.73 \pm 0.13$ & $7.80 \pm 0.01$ & 7.899 & 7.902 & & & \\
\hline 1250 & $7.72 \pm 0.04$ & & & & & & & & \\
\hline 1860 & & $7.59 \pm 0.00$ & $7.56 \pm 0.11$ & $7.68 \pm 0.04$ & & & & & \\
\hline 2340 & & & & & & & & $7.46 \pm 0.03$ & \\
\hline 3860 & & $7.35 \pm 0.04$ & $7.33 \pm 0.08$ & $7.34 \pm 0.02$ & & & & & \\
\hline 5090 & & & & & & & & & $7.3 \pm 0.03$ \\
\hline 8860 & & $7.03 \pm 0.07$ & $7.16 \pm 0.06$ & $7.13 \pm 0.01$ & & & & & \\
\hline 18860 & & $6.83 \pm 0.01$ & $6.95 \pm 0.10$ & $6.78 \pm 0.00$ & & & & & \\
\hline 22470 & & & & & & & & $6.63 \pm 0.11$ & \\
\hline
\end{tabular}



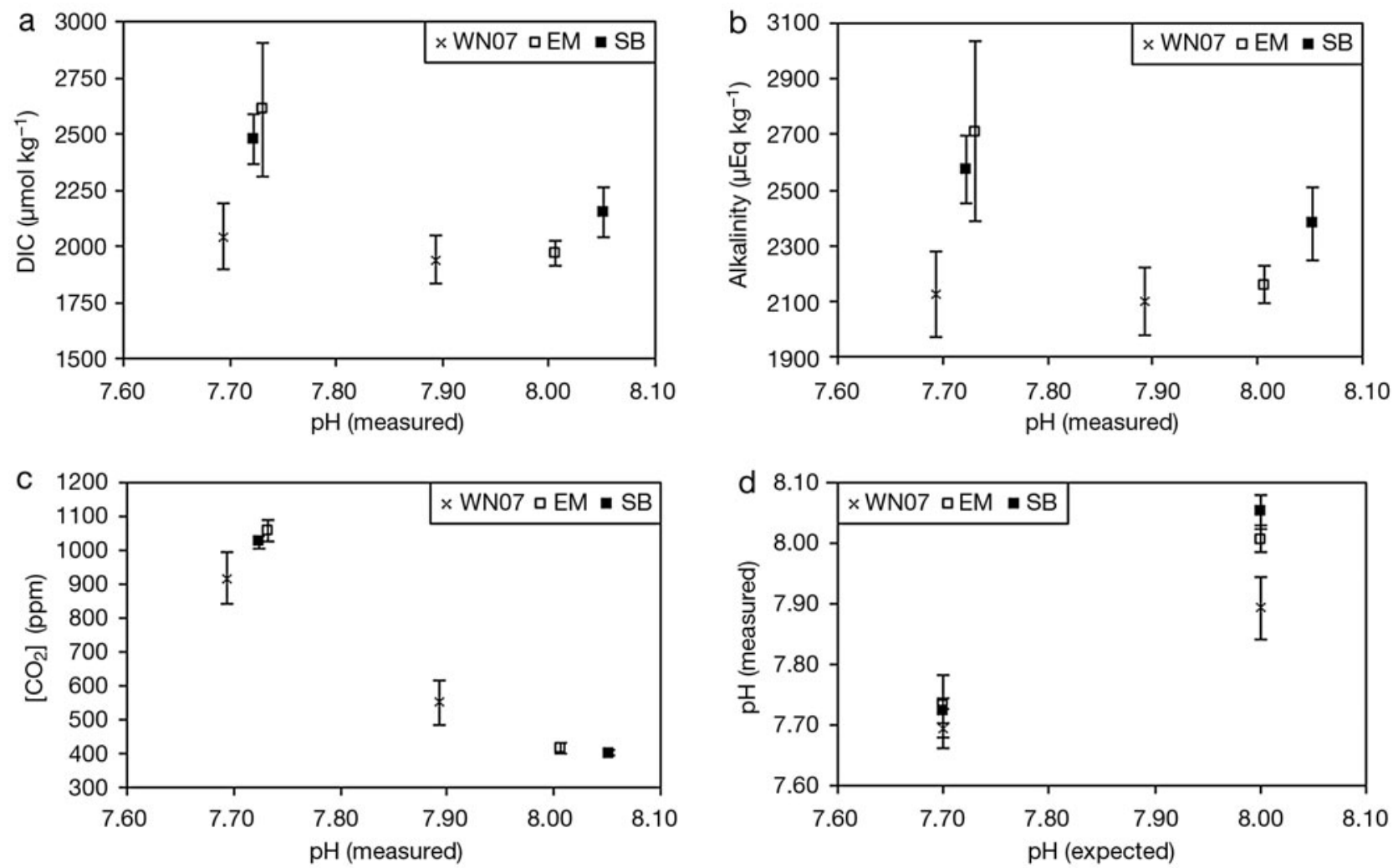

Fig. 5. Carbonate system values from an experiment using the Widdicombe \& Needham (2007) set-up ( $\mathrm{x}$, WN07), from the initial experiment described here $(\mathbf{\square}, \mathrm{SB})$ and from a second experiment using the same equipment as SB, but using a different species $(\square$, EM). Values are calculated for the experimental periods, mean $\pm 95 \%$ CI. (a) Total dissolved inorganic carbon (DIC) plotted against mean measured $\mathrm{pH}$ over the experimental period, (b) alkalinity plotted against mean measured pH over the experimental period, (c) $\left[\mathrm{CO}_{2}\right]$ plotted against mean measured $\mathrm{pH}$ over the experimental period, and (d) $\mathrm{pH}$ plotted against expected/target $\mathrm{pH}$

expected and have larger uncertainty than the set-up of Widdicombe \& Needham (2007).

In any application of the system described here it is important also to consider daily and seasonal variability. We chose to maintain the conditions with minimal variability in order to investigate a specific time period within an organism's life-cycle. However, observations have shown that there is a natural seasonal cycle of $\mathrm{pH},\left[\mathrm{CO}_{2}\right]$ and temperature. $\mathrm{pH}$ in the intertidal zone is thought to vary annually by about 1 unit, reaching highest levels ( 8.5) during winter and lowest ( 7.5) in summer, as a result of varying levels of biological production and temperature (Hinga 2002); $\left[\mathrm{CO}_{2}\right]$ also has seasonal and daily cycles as a result of changes in DIC and alkalinity. In the North Atlantic there is a decrease in sea surface $\left[\mathrm{CO}_{2}\right]$ in summer and an increase in winter, predominantly as a result of biological productivity (Sarmiento \& Gruber 2006). This system can run for a long period, and, with minor alterations, it would be possible to reproduce seasonal variability in atmospheric $\left[\mathrm{CO}_{2}\right]$ together with a seasonally varying temperature regime (as demonstrated by the longer term Semibalanus balanoides experiment). Such a capability enables investigation of longer term climate change impacts on whole life cycles of short-lived organisms.

This initial proof-of-concept study has demonstrated that the microcosm system is ideal for small-scale studies and thereby justifies further studies with greater replication. Although we acknowledge that size matters (Schindler 1998), these microcosm systems allow us to focus on specific conditions and endpoint measures in a subject area that is lacking in fundamental data. These microcosms are appropriate for studying organisms from a variety of near-surface environments with a variety of substratum types. The system as described here is relatively small and easy to set up, which makes it adaptable to many locations. Here, we used a controlled-temperature environment to maintain ambient conditions and a similar room would be necessary if the in situ conditions were highly variable on a daily basis or if the required target conditions were lower than those of the ambient conditions. The ability to move the systems between locations means that the system can reduce longdistance transport of animals and so minimise experimental artefacts resulting from handling and transport. 
Acknowledgements. H.S.F. acknowledges funding from NERC Blue Skies PhD NER/S/A/2006/14324. This work also contributes to the NERC-funded programme Oceans 2025 (Theme 3-Coastal and shelf processes). The authors also thank Hannah Wood, Amanda Beesley and Andrea McEvoy for assisting with experimental operations.

\section{LITERATURE CITED}

Baulch HM, Nord TW, Ackerman MY, Dale JD, Hazewinkel RRO, Schindler DW, Vinebrooke RD (2003) Climate warming experiments: design of a mesocosm heating system. Limnol Oceanogr Methods 1:10-15

Beaugrand G, Reid PC (2003) Long-term changes in phytoplankton, zooplankton and salmon related to climate. Glob Change Biol 9:801-817

Burke L, Maidens J (2004) Reefs at risk in the Caribbean. World Resources Institute, Washington, DC

> Caldeira K, Wickett ME (2003) Anthropogenic carbon and ocean pH. Nature 425:365

Cameron JN, Iwama GK (1987) Compensation of progressive hypercapnia in channel catfish and blue crabs. J exp Biol 133:183-197

Chen CTA, Lie KK, Macdonald R (2003) Continental margin exchanges. In: Fasham MJR (ed) Ocean biogeochemistry: a JGOFS synthesis. Springer-Verlag, Heidelberg, p 53-97

Chen CTA, Andreev A, Kim KR, Yamamoto M (2004) Roles of continental shelves and marginal seas in the biogeochemical cycles of the North Pacific Ocean. J Oceanogr 60:17-44

Dales RP, Mangum CP, Tichy JC (1970) Effects of changes in oxygen and carbon dioxide concentrations on ventilation rhythms in onuphid polychaetes. J Mar Biol Assoc UK 50: 365-380

Delille B, Harlay J, Zondervan I, Jacquet S and others (2005) Response of primary production and calcification to changes of $\mathrm{pCO}_{2}$ during experimental blooms of the coccolithophorid Emiliania huxleyi. Global Biogeochem Cycles 19:GB2023

Fabry VJ (1990) Shell growth rates of pteropod and heteropod molluscs and aragonite production in the open ocean: implications of the marine carbonate system. J Mar Res 48:209-222

> Gattuso JP, Frankignoulle M, Bourge I, Romaine S, Buddemeier RW (1998a) Effect of calcium carbonate saturation of seawater on coral calcification. Global Planet Change 18: $37-46$

Gattuso JP, Frankignoulle M, Wollast R (1998b) Carbon and carbonate metabolism in coastal aquatic ecosystems. Annu Rev Ecol Syst 29:405-434

Green MA, Jones ME, Boudreau CL, Moore RL, Westman BA (2004) Dissolution mortality of juvenile bivalves in coastal marine deposits. Limnol Oceanogr 49:727-734

Guinotte JM, Orr J, Cairns S, Freiwald A, Morgan L, George $\mathrm{R}$ (2006) Will human induced changes in seawater chemistry alter the distribution of deep-sea scleractinian corals? Front Ecol Environ 4:141-146

Hays GC, Richardson AJ, Robinson C (2005) Climate change and marine plankton. Trends Ecol Evol 20:337-344

> Hinga KR (2002) Effects of pH on coastal marine phytoplankton. Mar Ecol Prog Ser 238:281-300

IPCC (Intergovernmental Panel on Climate Change) (2007) Climate change 2007: the physical science basis. In: Solomon S, Qin D, Manning M, Chen Z and others (eds) Contribution of Working Group I to the 4th assessment report of the Intergovernmental Panel on Climate Change. Cam- bridge University Press, Cambridge

Kleypas JA, Feely RA, Fabry VJ, Langdon C, Sabine CL, Robbins LL (2006) Impacts of ocean acidification on coral reefs and other marine calcifiers: a guide for future research. Report of a workshop held 18 to 20 April 2005, St. Petersburg, FL. Sponsored by NSF, NOAA, and the U.S. Geological Survey

Kurihara H, Shirayama Y (2004) Effects of increased atmospheric $\mathrm{CO}_{2}$ on sea urchin early development. Mar Ecol Prog Ser 274:161-169

> Kurihara H, Shimode S, Shirayama Y (2004) Sub-lethal effects of elevated concentrations of $\mathrm{CO}_{2}$ on planktonic copepods and sea urchins. J Oceanogr 60:721-727

Levitus S, Antonov J, Boyer T (2005) Warming of the world ocean, 1955-2003. Geophys Res Lett 32:L02604

Liboriussen L, Landkildehus F, Meerhoff M, Bramm ME and others (2005) Global warming: design of a flowthrough shallow lake mesocosm climate experiment. Limnol Oceanogr Methods 3:1-9

Loeng $H$, Brander K, Carmack E, Denisenko S and others (2005) Marine systems. In: Symon C, Arris L, Heal B (eds) Arctic climate impact assessment, ACIA. Cambridge University Press, Cambridge, p 453-538

McKee D, Atkinson D, Collings S, Eaton J and others (2000) Heated aquatic microcosms for climate change experiments. Freshw Forum 14:51-58

MacKenzie BR, Schiedek D (2007) Long-term sea surface temperature baselines - time series, spatial covariation and implications for biological processes. J Mar Syst 68: 405-420

Mehrbach C, Culberson CH, Hawley JE, Pytkowicz RM (1973) Measurements of the apparent dissociation constants of carbonic acid in seawater at atmospheric pressure. Limnol Oceanogr 18:897-907

Metzger R, Sartoris FJ, Langenbuch M, Pörtner HO (2007) Influence of elevated $\mathrm{CO}_{2}$ concentrations on thermal tolerance of the edible crab Cancer pagurus. J Therm Biol 32:144-151

> Michaelidis B, Ouzounis C, Paleras A, Pörtner HO (2005) Effects of long-term moderate hypercapnia on acid-base balance and growth rate in marine mussels Mytilus galloprovincialis. Mar Ecol Prog Ser 293:109-118

Michaelidis B, Spring A, Pörtner HO (2007) Effects of longterm acclimation to environmental hypercapnia on extracellular acid-base status and metabolic capacity in Mediterranean fish Sparus aurata. Mar Biol 150:1417-1429

Miles H, Widdicombe S, Spicer JI, Hall-Spencer J (2007) Effects of anthropogenic seawater acidification on acidbase balance in the sea urchin Psammechinus miliaris. Mar Pollut Bull 54:89-96

Munro Fox H, Johnson ML (1934) The control of respiratory movements in Crustacea by oxygen and carbon dioxide. $\mathrm{J}$ exp Biol 11:1-10

Orr JC, Fabry VJ, Aumont O, Bopp L and others (2005) Anthropogenic ocean acidification over the twenty-first century and its impact on calcifying organisms. Nature 437:681-686

Pane EF, Barry JP (2007) Extracellular acid-base regulation during short-term hypercapnia is effective in a shallowwater crab, but ineffective in a deep-sea crab. Mar Ecol Prog Ser 334:1-9

Pörtner HO (1987) Anaerobic metabolism and changes in acid-base status: quantitative interrelationships and $\mathrm{pH}$ regulation in the marine worm Sipunculus nudeus. J Exp Biol 131:89-105

Pörtner HO, Reipschläger A, Heisler N (1998) Metabolism and acid-base regulation in Sipunculus nudus as a func- 
tion of ambient carbon dioxide. J Exp Biol 201:43-55

Pörtner HO, Langenbuch M, Reipschlager A (2004) Biological impact of elevated ocean $\mathrm{CO}_{2}$ concentrations: lessons from animal physiology and earth history. J Oceanogr 60: $705-718$

Pörtner HO, Langenbuch M, Michaelidis B (2005) Synergistic effects of temperature extremes, hypoxia and increases in $\mathrm{CO}_{2}$ on marine animals: from earth history to global change. J Geophys Res 110:C09S10

Raven J, Caldeira K, Elderfield H, Hoegh-Guldberg $\mathrm{O}$ and others (2005) Ocean acidification due to increasing atmospheric carbon dioxide. The Royal Society policy document 12/05. Clyvedon Press, Cardiff

Riebesell U, Wolf-Gladrow DA, Smetacek V (1993) Carbon dioxide limitation of marine phytoplankton growth rates. Nature 361:249-251

Sarmiento JL, Gruber N (2006) Ocean biogeochemical dynamics. Princeton University Press, Princeton, NJ, p 318-353

Schindler DW (1998) Replication versus realism: the need for ecosystem-scale experiments. Ecosystems 1:323-334

Shirayama Y, Thornton H (2005) Effect of increased atmospheric $\mathrm{CO}_{2}$ on shallow water marine benthos. J Geophys Res 110:C09S08

Initial editorial responsibility: Howard Browman, Storebø, Norway; final editorial responsibility: Hans Heinrich Janssen, Oldendorf/Luhe, Germany
Southward AJ, Hawkins SJ, Burrows MT (1995) Seventy years' observations of changes in distribution and abundance of zooplankton and intertidal organisms in the western English Channel in relation to rising sea temperature. J Therm Biol 20:127-155

Turley C, Blackford JC, Widdicombe S, Lowe D, Nightingale PD, Rees AP (2006) Reviewing the impact of increased atmospheric $\mathrm{CO}_{2}$ on oceanic $\mathrm{pH}$ and the marine ecosystem. In: Schellnhuber HJ, Cramer W, Nakjcenovic N, Wigley $\mathrm{T}$, Yohe $\mathrm{G}$ (eds) Avoiding dangerous climate change, Vol 8. Cambridge University Press, Cambridge, p 65-70

- Ver LMB, Mackenzie FT, Lerman A (1999) Carbon cycle in the coastal zone: effects of global perturbations and change in the past three centuries. Chem Geol 159: 283-304

Widdicombe $\mathrm{S}$, Needham HR (2007) Impact of $\mathrm{CO}_{2}$-induced seawater acidification on the burrowing activity of Nereis virens and sediment nutrient flux. Mar Ecol Prog Ser 341: 111-122

Zeebe RE, Wolf-Gladrow DA (2001) $\mathrm{CO}_{2}$ in seawater: equilibrium, kinetics, isotopes. Elsevier Oceanography Series 65, Amsterdam

Submitted: October 22, 2007; Accepted: May 16, 2008

Proofs received from author(s): July 2, 2008 